\title{
Reproductive Capacity and Sex-Ratio of Noemachelius multifasciatus Day from Mandal River, India.
}

\author{
Pankaj Bahuguna $^{1} \bullet$ Hemant Kumar Joshi ${ }^{2 *} \cdot$ Shraddha $^{\text {Bharti }^{1}}{ }^{\bullet}$ Smita Badola $^{3} \bullet$ A.K. \\ Dobriyal $^{4}$ \\ ${ }^{1}$ Aquatic Biodiversity Lab, Department of Zoology, B.D.Govt..P.G. College Jaiharikhal-246193, Uttarakhand, \\ India. \\ ${ }^{2}$ Department of Zoology, Govt. Degree College Chaubattakhal, Pauri Garhwal - 246162, UK \\ ${ }^{3}$ Department of Zoology, SDS University Campus, Rishikesh, Uttarakhand. \\ 4.Department of Zoology, B.G.R.Campus Pauri, H.N.B.Garhwal (A Central University) University, Pauri \\ Garhwal-246001.
}

*Corresponding author: drjoshihk2013@gmail.com

Received: 10.10.2021; Revised: 12.11.2021; Accepted: 22.12.2021

CSociety for Himalayan Action Research and Development

\begin{abstract}
Present communication deals with the reproductive capacity and sex ratio of a hill stream ornamental fish, Noemacheilus multifasciatus Day from river Mandal of Garhwal region, Uttarakhand, India. A total 151 specimens were collected for this investigation from Mandal River during October 2020 to September 2021. The morphometric measurements were made within 2-3 days of collection which were total length (TL) fish body weight (F.B.W) ovary length and ovary weight. For the assessment of reproductive capacity, anterior, middle and the posterior part of ovary were taken and number of ova in each sample was counted with the help of binocular microscope. The reproductive capacity in terms of absolute fecundity was calculated as $\mathrm{F}=\mathrm{S}$. OW/100. Sex ratio was calculated for whole period of study and its signification was tested by Chi-Square test $\left(\chi^{2}\right)$. The length of fishes ranged from $56 \mathrm{~mm}$ to $80 \mathrm{~mm}$ whereas fish body weight varied from $2138 \mathrm{mg}$ to 6347 mg.. The lowest reproductive capacity (175 eggs) was observed for the fish length $56 \mathrm{~mm}$, and body weight $2138 \mathrm{mg}$. whereas highest reproductive capacity (3476 eggs) was estimated in fish measuring $80 \mathrm{~mm}$ length and fish body weight $6347 \mathrm{mg}$. The reproductive capacity was more dependent on the ovary length $(\mathrm{r}=0.9894)$ and fish weight $(\mathrm{r}=0.9812)$, than the fish ovary weight $(0.9786)$ and fish length $(0.9248)$. The average ratio was 1.16 for female: 1.0 for male.
\end{abstract}

Key words: Noemacheilus multifasciatus, reproductive capacity, sex-ratio, river Mandal.

\section{Introduction}

Noemacheilus multifasciatus Day is a beautiful

hill stream loach inhabiting the small streams and river of Garhwal Himalaya.The knowledge on the reproductive biology is essential in understanding life history, stock management and successful culture of a fish species. The fecundity indicates the reproductive potential of a fish during one spawning season. Several ichthyologists have reported a variety of information on the breeding biology of hillstream fishes (Dobriyal 1988, 2012; Dobriyal et.al, 2004, 2010; Bahuguna et.al, 2007, 2009, 2010; 2021a-b; Joshi et.al 2010, 2013; Bahuguna and Kumar, 2011a; Krishan et.al, 2011a; Bahuguna 2012; Rashid and Dobriyal, 2020; Rayal et.al, 2021c), The Sex-Ratio of fish has also been studied by several authors which is an important aspect of fish biology (Dobriyal and Singh, 1989; Kumar et.al, 2006; Dobriyal 2011; Bahuguna and Kumar, 2011b; Krishan et.al, 2011b; Bahuguna et.al 2010a-b-f, 2011; Bahuguna and Balodi 2015; Joshi et.al, 2014; Rayal et.al 2021d). Sexual dimorphism is $n$ another aspect to be evaluated under breeding biology (Badola et.al, 1982; Dobriyal et.al 2007; Bahuguna et.al; 2010c) of Indian fishes. Present communication deals with the 
reproductive capacity and sex ratio of a hill stream ornamental fish, Noemacheilus multifasciatus Day from river Mandal of Garhwal region, Uttarakhand, India.

\section{Material and Methods}

Fishes was collected by way of the traditional fishing gears (Bahuguna et.al, 2010e; Bahuguna and Joshi, 2012: Bahuguna 2020, 2021; Rayal et.al., 2021a-b). The samples were immediately preserved with $5 \%$ formalin solution. A total 151 specimens were collected for this investigation from Mandal River during October 2020 to September 2021.

Laboratory Work: The morphometric measurements were made within 2-3 days of collection which were total length (TL) fish body weight (F.B.W) ovary length and ovary weight. For the assessment of reproductive capacity, anterior, middle and the posterior part of ovary were taken and number of ova in each sample was counted with the help of binocular microscope. The reproductive capacity in terms of absolute fecundity was calculated as $\mathrm{F}=\mathrm{S}$. OW/100

Where, $\mathrm{F}=$ Fecundity, OW = Total weight of ovary, $S=$ Average number of ova from samples of $100 \mathrm{mg}$ each (anterior, middle and the posterior part of ovary) The mathematical relationship between Reproductive capacity and other body parameters were obtained by least square test, using the formula as $\mathrm{Y}=\mathrm{a}+$ bx, where $\mathrm{Y}=$ (Reproductive Capacity, dependent variable), $\mathrm{x}=$ Body parameters (independent variable); $\mathrm{a}=$ Slope and $\mathrm{b}=$ Intercept.
Sex ratio was calculated for whole period of study and its signification was tested by ChiSquare test $\left(\chi^{2}\right)$ using the following equation-

$$
\chi^{2}=\sum \frac{(O-E)^{2}}{E}
$$

Where; $\mathrm{O}=$ Observed value, $\mathrm{E}=$ Expected value. Significance was determined by using table value at $\mathrm{F}_{0.05}$ variable..

\section{Result s and Discussion}

The Reproduction capacity and different body parameters are presented in the Table 1 . The length of fishes ranged from $56 \mathrm{~mm}$ to $80 \mathrm{~mm}$ whereas fish body weight varied from $2138 \mathrm{mg}$ to $6347 \mathrm{mg}$.. The lowest reproductive capacity (175 eggs) was observed for the fish length $56 \mathrm{~mm}$, and body weight $2138 \mathrm{mg}$. whereas highest reproductive capacity (3476 eggs) was estimated in fish measuring $80 \mathrm{~mm}$ length and fish body weight $6347 \mathrm{mg}$.

The relationships of reproductive capacity with different independent body parameters (F.L., F.W., O.L. \& O.W.) were observed straight and presented in Fig 1 to 4. Mathematical equations obtained were as follow: The equation $(\mathrm{RC}=\mathrm{a}+\mathrm{b} \cdot \mathrm{x})$.

R.C $=-6447.4+115.71 \mathrm{FL}, \mathrm{r}=0.9248 ; \mathrm{r}^{2}=$ 0.8553 (Fig.1)

R.C $=-1626.1+00.753 \mathrm{FW}, \mathrm{r}=0.9812 ; \quad \mathrm{r}^{2}=$ 0.9629 (Fig.2) 
Table 1: Reproductive Capacity of hill-stream loach Noemacheilus multifasciatus Day from Mandal River.

\begin{tabular}{|c|c|c|c|c|c|c|}
\hline $\begin{array}{l}\text { Fish } \\
\text { Size } \\
(\mathrm{mm})\end{array}$ & $\begin{array}{l}\text { Fish } \\
\text { Length } \\
(\mathrm{mm})\end{array}$ & $\begin{array}{l}\text { Fish weight } \\
\text { (mg) }\end{array}$ & $\begin{array}{l}\text { Ovary } \\
\text { Length } \\
(\mathrm{mm})\end{array}$ & $\begin{array}{l}\text { Ovary weight } \\
\text { (mg) }\end{array}$ & $\begin{array}{l}\text { Reproductiv } \\
\text { e capacity }\end{array}$ & $\begin{array}{l}\text { No. of } \\
\text { fish }\end{array}$ \\
\hline $55-60$ & $\begin{array}{l}56-59 \\
57.54 \pm 1.05\end{array}$ & $\begin{array}{l}2138-2314 \\
2217 \pm 119.20\end{array}$ & $\begin{array}{l}11-15 \\
13.09 \pm 1.45\end{array}$ & $\begin{array}{l}231-273 \\
258.6 \pm 17.11\end{array}$ & $\begin{array}{l}175-242 \\
219.11 \pm 20\end{array}$ & 04 \\
\hline $61-65$ & $\begin{array}{l}62-65 \\
63.44 \pm 0.40\end{array}$ & $\begin{array}{l}2454-2654 \\
2527.2 \pm 89.57\end{array}$ & $\begin{array}{l}13-16 \\
14.22 \pm 1.10\end{array}$ & $\begin{array}{l}307-454 \\
376.5 \pm 29.89\end{array}$ & $\begin{array}{l}276-397 \\
334.21 \pm 43.9\end{array}$ & 05 \\
\hline $66-70$ & $\begin{array}{l}67-70 \\
68.52 \pm 1.08\end{array}$ & $\begin{array}{l}2897-3673 \\
3255.15 \pm 189.7 \\
3\end{array}$ & $\begin{array}{l}17-22 \\
19.87 \pm 1.20\end{array}$ & $\begin{array}{l}460-661 \\
568.70 \pm 29.40\end{array}$ & $\begin{array}{l}384-795 \\
601 \pm 89\end{array}$ & 05 \\
\hline $71-75$ & $\begin{array}{l}72-75 \\
74.01 \pm 0.20\end{array}$ & $\begin{array}{l}3893-4785 \\
4436.42 \pm 227.3 \\
1\end{array}$ & $\begin{array}{l}23-28 \\
25.24 \pm 1.75\end{array}$ & $\begin{array}{l}543-877 \\
687.2 \pm 76.37\end{array}$ & $\begin{array}{l}786-1978 \\
1502 \pm 309\end{array}$ & 08 \\
\hline $76-80$ & $\begin{array}{l}77-80 \\
79.40 \pm 0.11\end{array}$ & $\begin{array}{l}4876-6347 \\
5589 \pm 479.50\end{array}$ & $\begin{array}{l}34-39 \\
36.55 \pm 2.15\end{array}$ & $\begin{array}{l}1043-1576 \\
1289.78 \pm \\
157.42\end{array}$ & $\begin{array}{l}2168-3476 \\
2786.3 \pm 542\end{array}$ & 05 \\
\hline
\end{tabular}

Min - Max* Average \pm SD
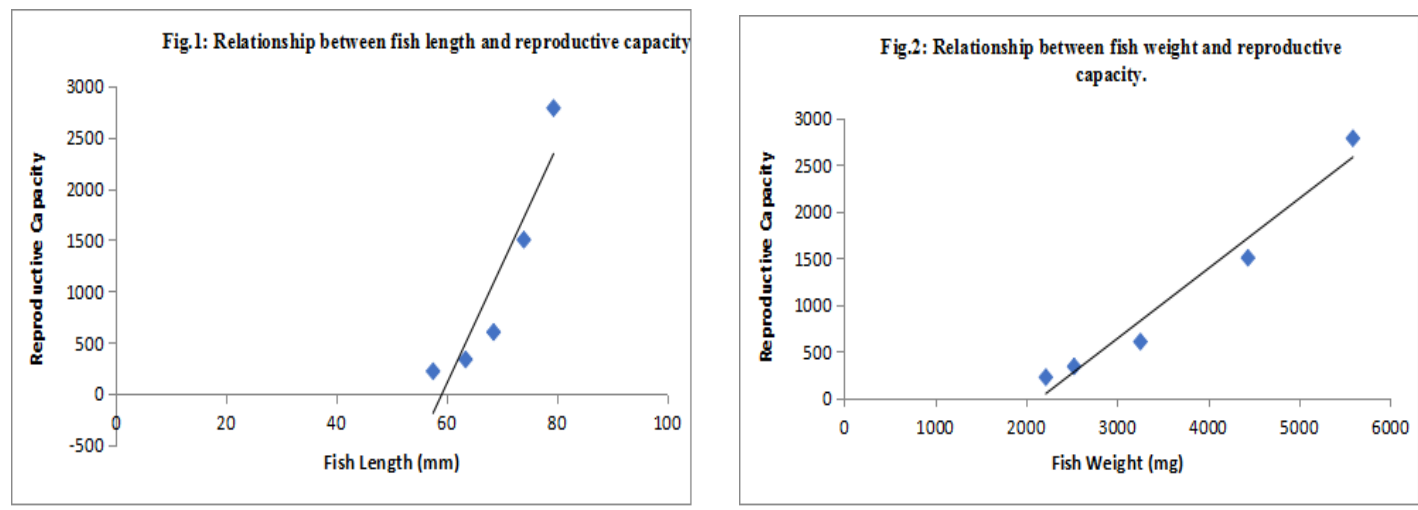

R.C $=-1331.8+111.06$ OL, $r=0.9894 ; \quad r^{2}=0.9791$ (Fig.3)

R.C $=-577.83+2.6194$ OW, $r=0.9786 ; r^{2}=0.9578$ (Fig.4)
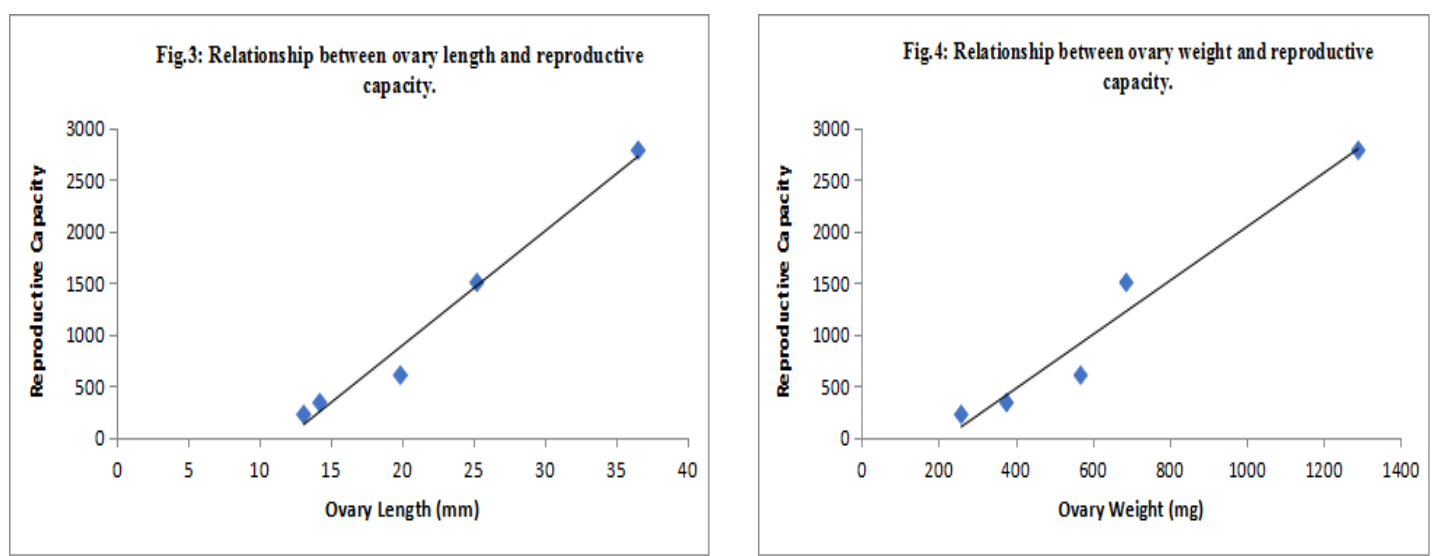

(Where R.C = Reproductive Capacity, FL = Fish length, FW = Fish weight, OL= Ovary length, OW = Ovary weight and $\mathrm{r}=$ coefficient of correlation). 
The reproductive capacity was more dependent on the ovary length $(r=0.9894)$ and fish weight $(r=0.9812)$, than the fish ovary weight (0.9786) and fish length (0.9248).

The sex-ratio of Noemacheilus multifasciatus observed from river Mandal during October 2020 to September 2021 is presented in Table 2. A total 156 (72 Male and 84 female fish) number of fishes were collected during the field work. The percentage of female fishes were 53.85 and male fishes were 46.15 , the average ratio was 1.16 for female: 1.0 for male.

Hill stream fishes show a variation in their reproductive potential. Absolute reproductive capacity of Noemacheilus multifasciatus ranged from 2138 to 3476 eggs which increases with an increase in all independent body parameters. According to Ritu and Nair (1979) in Noemacheilus triangularis, the average fecundity ranged from 800 to 2126 eggs. The breeding capacity of $B$. bendelisis was observed from 900-5048 in the fish measuring 7.5-11.5 $\mathrm{cm}$ and ovary weighing from $700 \mathrm{mg}$ to $2.42 \mathrm{gm}$ (Dobriyal and Singh, 1987). Noemacheilus botia (Ham.) in the Khoh river was observed by Singh (2004) with its fecundity ranging from 447-1631 in the fish measuring just 51-80mm. Bahuguna et.al, (2007) observed that fecundity varies from 360 to 1727 for Puntius conchonius (HamBuch).

Table 2: Monthly variation in the sex-ratio of Noemacheilus multifasciatus Day during October 2020 to September 2021 from River Mandal.

\begin{tabular}{|c|c|c|c|c|c|c|c|c|c|}
\hline Month & $\begin{array}{l}\text { Total no } \\
\text { of fish } \\
\text { examine } \\
\text { d }\end{array}$ & $\begin{array}{l}\text { No. of } \\
\text { male } \\
\text { fish }\end{array}$ & $\begin{array}{l}\text { No. of } \\
\text { female } \\
\text { fish }\end{array}$ & $\begin{array}{l}\% \text { of } \\
\text { Male } \\
\text { fish }\end{array}$ & $\begin{array}{l}\% \text { of } \\
\text { female } \\
\text { fish }\end{array}$ & $\begin{array}{l}\text { Sex } \\
\text { ratio } \\
\text { male }\end{array}$ & $\begin{array}{l}\text { Sex } \\
\text { ratio } \\
\text { female }\end{array}$ & $\begin{array}{l}\text { Chi- } \\
\text { square }\end{array}$ & $\begin{array}{l}\text { Remar } \\
\text { ks }\end{array}$ \\
\hline Oct., 2020 & 06 & 03 & 03 & 50.00 & 50.00 & 1.0 & 1.0 & 0.000 & NS \\
\hline Nov., 2020 & 09 & 04 & 05 & 44.45 & 55.55 & 1.0 & 1.25 & 0.111 & NS \\
\hline Dec., 2020 & 10 & 06 & 04 & 60.00 & 40.00 & 1.5 & 1.0 & 0.400 & NS \\
\hline Jan., 2021 & 09 & 04 & 05 & 44.45 & 55.55 & 1.0 & 1.25 & 0.111 & NS \\
\hline Feb., 2021 & 09 & 05 & 04 & 55.55 & 45.45 & 1.25 & 1.0 & 0.111 & NS \\
\hline Mar., 2021 & 11 & 05 & 06 & 44.55 & 54.56 & 1.0 & 1.2 & 0.090 & NS \\
\hline Apr., 2021 & 10 & 05 & 05 & 50.00 & 50.00 & 1.0 & 1.0 & 0.000 & NS \\
\hline May.,2021 & 15 & 06 & 09 & 40.00 & 60.00 & 1.0 & 1.14 & 0.600 & NS \\
\hline Jun., 2021 & 21 & 09 & 12 & 42.86 & 57.14 & 1.0 & 1.33 & 0.428 & NS \\
\hline July.,2021 & 25 & 09 & 16 & 36.00 & 64.00 & 1.0 & 1.77 & 1.960 & NS \\
\hline Aug., 2021 & 19 & 08 & 11 & 42.11 & 57.89 & 1.0 & 1.37 & 0.473 & NS \\
\hline Sep., 2021 & 07 & 04 & 03 & 57.14 & 42.86 & 1.33 & 1.0 & 0.285 & NS \\
\hline Total & 151 & 67 & 84 & 44.37 & 55.63 & 1.0 & 1.25 & 1.913 & NS \\
\hline
\end{tabular}

$\mathrm{X}^{2}=$ values are no significant at either level (d.f.1 on $\mathrm{p}=0.05$ is 3.84 ): $\mathrm{M}=$ male, $\mathrm{F}=$ Female. $\mathrm{NS}=$ non-significant.

The fecundity of Tor chelynoides (McClelland) has been calculated as 1265 to 
9284 in the fish measuring $7.5-11.5 \mathrm{~cm}$ and ovary weight 1-15.6 $\mathrm{g}$ from the spring fed river Western Nayar (Uniyal, 2003). The fecundity of Botia dayi ranged from 2,225 to 8,840 for the fish measuring 10.1 to $14.5 \mathrm{~cm}$ and weighing $17.72 \mathrm{gm}$. to $38.6 \mathrm{gm}$. (Kumar et.al., 2006). The fecundity of Barilius vagra was estimated by Bahuguna et.al. (2009) from Garhwal region oscillated from 510 to 7214 eggs in fish measuring $55 \mathrm{~mm}$ to $89 \mathrm{~mm}$ in total length and $407 \mathrm{mg}$ to $4260 \mathrm{mg}$ ovarian weight. In the present study, an overall average sex ratio of 1.00 Male: 1.25 female was found in Noemacheilus multifasciatus from Mandal River. Overall average sex ratio was found to be non-significant. The $N$. triangularis male and female fish are present in more or less equal number as out of the total of 507 fish sexed, 269 (1.13 Ratio) are Male and 238 (1 Ratio) female noticed by Rita Kumari and Nair (1979) in Kallar River. Dobriyal et.al,(2004) observed the sex ratio of 1.00 male: 1.028 female during their study in Crossocheilus latius latius from the river Mandakini which was very close to the natural population ratio.

The sex composition of Garra lamta was 1 Male : 1female in the spring feed water body from Pithoragarh district in Kumaun Region (Bahuguna et.al, 2010). Bahuguna and Balodi (2015) reported a 1.171 Male: 1.00 female sex ratio in Labeo dyocheilus from the western Ram Ganga River which was significant. $B$. barna sex-ratio composition was noticed 1.00 male : 1.08 female in river Tamsa from Doon valley, India (Bahuguna et.al, 2021a). The optimum sex ratio may very drastically by numerous factor and it may also depend on different population inhibiting different regions which show difference in sex-ratios (Nikolsky 1956,80).

\section{Reference}

Badola, S.P., Singh, H.R. and Dobriyal, A.K. (1982). Note on sexual dimorphism in Barilius bendelisis (Ham) Indian $J$. Anim. Sci. 52: 1284-1286.

Bahuguna, P. (2021). Distribution pattern of Ichthyofauna diversity in different habitats in the first second and third order stream of Randi Gad from Garhwal Himalaya, India. Natl. Acad. Sci. Lett. 44(5): 393-395. https://doi.org/10.1007/s40009-02001032-9

Bahuguna, P., Saklani, S., Rayal, R. and Madan, S. (2021a). Assessment of breeding capacity and sex-ratio of Barilius barna (Hamilton) in springfed Tamsa stream, Garhwal region, India. Uttar Pradesh Journal of Zoology. 42(16): 1-8.

Bahuguna, P., Sharma, V., Rayal, R. and Negi, S. (2021b) Reproductive potential of Puntius ticto in foot hill river Aasan from Doon Valley, India. Env. BioSci. vol. 35(1).

Bahuguna, Pankaj (2012). Observation on Reproductive capacity of Wild carp Labeo dyochelius from Kumaun Himalaya, India. Essence J. vol. 3(1): $1-7$. 
Bahuguna, Pankaj (2020). Fish diversity in different habitats in the $1^{\text {st }}, 2^{\text {nd }}$ and $3^{\text {rd }}$ order stream of Kyunja Gad from Garhwal Himalaya, India. Uttar Pradesh Journal of Zoology. 41(3): 24-29.

Bahuguna, Pankaj and Balodi, V.P (2015). Sex composition observation of Labeo dyocheilus (McCllelland) from western Ram Ganga River, Uttrakhand, India. International Journal in Physical \& Applied Sciences Vol. 02 Issue-05: 75-81.

Bahuguna, Pankaj and H.K. Joshi (2012). A study on fish and fisheries of river Kalapani from Kumaun Himalaya, India. J. Mountain. Res. Vol. (7): 6771.

Bahuguna, Pankaj and Kumar, R. (2011a). Breeding capacity observation of snow fed water cat fish Pseudechenies sulcatus (McClelland) of the eastern ram Ganga river from Kumaon region, Uttarakhand. Aquacult. Vol. 12(1): 9398.

Bahuguna, Pankaj and Kumar, R. (2011b). Sex composition analysis of Himalayan cold water cat fish Pseudechenies sulcatus (McClelland) in eastern ram Ganga River, Uttrakhand, India. $J$. Natcon. 23(1):105-110

Bahuguna, Pankaj, Joshi, H.K and Dobriyal, A.K. (2010e). Conventional and Nonconventional fishing techniques used by rural folks in Mandal valley,
Uttarakhand. Uttar Pradesh J. Zool. 30(2): 221-223.

Bahuguna, Pankaj, Joshi, H.K., and Dobriyal, A.K. (2007). Fecundity and sex ratio in Puntius conchonius (Pieces: Cyprinidae) from Garhwal Himalaya. Enviromental conservation Journal 8(1-2): 37-43.

Bahuguna, Pankaj, Kumar, R. and Shah, K.K. (2010f). Studies on the reproductive capacity and sex ratio in a hill stream loach fish Noemacheilus denisonii day from river Mandal of Garhwal Himalaya, Uttrakhand. Uttar Pradesh J. Zool. 30(1): 71-76.

Bahuguna, Pankaj, Kumar, R., and Shah, K.K (2009). Breeding power and sex-ratio in Barilius vagra (Ham.) from spring fed river Mandal, Garhwal Himalaya, India. Aquacult. Vol 10(2): 279-283.

Bahuguna, Pankaj, Kumar, R., Bhatia, D. and Kumar, S. (2010d). Breeding capacity observation of the hill stream minor carp Barilius bendelisis (Ham-Buch) (Pisces: Cyprinidae) from mountain region of central Himalaya, India. $J$. Curr. Sci. Vol. 15 (1): 145-150.

Bahuguna, Pankaj, Kumar, R., Joshi, H.K., Baloda, V.P., Kotnala, C.B. and Bhatia, D., (2010a). Sex composition status in sucker head Gadale, Garra lamta (Ham-Buch.) in stream feed water bodies of Pithoragarh District, Uttrakhand, India. J. Natcon. 22 (1): 19-24. 
Bahuguna, Pankaj, Kumar, R., Rakesh Verma and Bhatia, D. (2010b). Estimation on the sex composition of Barilius bendelisis (Ham-Butch) (Pieces Cyprinidae) from Kumaun region of Central Himalaya, India. Indian. $J$. Environ. and Ecoplan. Vol. 17 (1-2): 85-88.

Bahuguna, Pankaj, Kumar, S., Kumar, R., Joshi, H.K. and Verma, R. (2010c). Studies on Sexual dimorphism in the Cyprinidae fish Puntius ticto (Hamilton-Buchanan) from Kumaun Himalaya, India. Essence. J. Vol.1 (2): 88-93.

Bahuguna, Pankaj., Joshi, H.K. and Kumar, R. (2011). Sex population status of Lepedocephalythys guntea (Hamilton) in the lotic water body of Pauri Garhwal. Uttar Pradesh J. Zool. 31(1): 349-355.

Dobriyal A.K (1988). Fecundity of the Chinese silver carp Hypophthalmichthys molitrix (Val.) from Gujaratal Fish Farm, Jaunpur, U.P. Proc. Indian Acad. Sci. (Anim. Sci.); 97(2): 169-173.

Dobriyal A.K (2011). Conservational biology of cobitid fish Lepidocephalus guntea (Hamilton-Buchanan): Population structure. J. Mountain Res. 6: 29-34.

Dobriyal A.K., Bahuguna, P.K., Uniyal, S, P. and Joshi, H.K. (2007). Sexual dimorphism in the Cyprinidae fish Puntius conchonius (Ham-Butch). J. Bom.Nat. Hist. Soc. 104 (2): 227-228.
Dobriyal A.K., Negi, K.S., Joshi, H.K. and Bisht, K.L. (2004). Breeding capacity of Crossocheillus latius latius (Pieces: Cyprinidae) in the river Mandakini of Garhwal , Uttrakhand. Flora and Fauna. 10(2): 151-153.

Dobriyal, A.K (2012). Conservational biology of cobitid fish Lepidocephalus guntea (Hamilton-Buchanan): Reproductive potential. J. sustn. Env. Res; 1(2):101105.

Dobriyal, A.K. and Singh, H.R. (1987). The reproductive biology of a hill stream minor carp Barilius bendelisis (Ham) from Garhwal Himalaya, India. Vest cs. Spolec. Zool. 51 : 1-10.

Dobriyal, A.K. and Singh, H.R. (1989). Ecology of rhithrofauna in the torrential water of Garhwal Himalaya, India: Fecundity and sex ratio of Glyptothorax pectinopterus (Pisces). Vest. Cs. Spolec. Zool. 53:17-25.

Dobriyal, A.K., Thapliyal, A., Joshi, H.K., Bahuguna, Pankaj and Balodi, V.P. (2010). Biology and Growth dynamics of hill stream cat fish Pseudecheneis sulcatus (McClelland) from Uttrakhand, India. Essence J. Vol. 1(2): $34-42$.

Joshi, Anita, Pramod Kumar, S.S.Kujwal and Bahuguna Pankaj (2014). Sex ratio of Noemacheilus montanus (Mcclelland) from Pithoragarh district, Uttarakhand, India. 
Int.J.Curr.Microbiol.App.Sci.Vol.3(12 ):761-767.

Joshi, Anita, Pramod Kumar and Bahuguna Pankaj (2013). Fecundity of Noemacheilus montanus from kumaon region. J. Mountain. Res. Vol. (8): 2936.

Joshi, H.K., Bahuguna, Pankaj, Kotnala, C.B. and Kumar, R. (2010). Reproduction power of the hill stream loach sune machi, Lepedocephalythys guntea (Hamilton) from mountain region of Garhwal, Central Himalaya, India. Aquacult. Vol. 11(1): 115-118.

Krishan, R., Dobriyal, A.K., Bisht, K.L., Kumar, R. and Bahuguna, Pankaj (2011a). Population ecology of the Indian torrent catfish, Amblyceps mangois (Ham-Buch). From Garhwal Uttrakhand, India. Int. J. Environ. Rehabi. And Conserv. Vol 2 (2): 2328.

Krishna, R., Dobriyal, A.K., and Bahuguna, Pankaj (2011b). Fecundity of Amblyceps mangois (HamiltonBuchanan) from Garhwal Himalaya. $J$. Mountain. Res. Vol. (6): 121-128.

Kumar, K., Bisht, K.L., Dobriyal, A.K., Joshi, H.K., Bahuguna, Pankaj, Goswami, S., Balodi, V.P. and Thapliyal, A. (2006). Fecundity and sex-ratio in a rare hill streams fish Botiya dayi Hora from Garhwal Himalaya, Uttaranchal. Uttar Pradesh J. Zool. 26(3): 271-276.
Nikolsky, G.V. (1956). The ecology of fishes. London Academic Press, New York: 1-352.

Nikolsky, G.V. (1980). Theory of fish population dynamics. Bishen singh and Mahendar Pal Singh, India and Ottokoeltz Science Publishers (West Germany), pp317.

Rashid, M. and Dobriyal, A.K (2020). Fecundity analysis of A Freshwater Fish Mastacembelus armatus (Lacepede) From river Nayar, Uttrakhand. J. Mountain Res. 15:18188.

Rayal R., Sharma, V., Bahuguna, P. and Mamgain D. (2021d). Sex ratio structure of Puntius ticto in spring fed River Aasan from District-Dehradun, Uttrakhand, India. Uttar Pradesh Journal of Zoology. 42(12): 49-53.

Rayal, R., Bhatt, A. and Bahuguna, P. (2021a). Fish fauna of River Yamuna from Doon valley, Uttrakhand, India. Journal of Experimental Zoology. Vol. 24(2): 973-977.

Rayal, R., Bhatt, A., Bahuguna, P. and Joshi, H. K. (2021b). Fish diversity of Mal Gad stream near Purola town from Uttarkashi district, Uttrakhand, India. Uttar Pradesh Journal of Zoology. 42 (8): 70-76.

Rayal, R., Saher A., Bahuguna, P, Negi, S. (2021c). Study on the breeding capacity of snow-fed trout, Schizothorax richardsonii (Gray) from river Yamuna, Uttrakhand, India. The 
Scientific temper (1-2) January- July: 87-93, 2020.

Rita Kumari, S. D. and Nair, N. B. (1979).

Maturation and spawning in the hill stream loach Noemachelius tringularis

(Day). Proc. Indian Acad. Sci., 88 (B):

45-54.

Sabet, M.H., Kamali, A.A., Soltani, M., Bani, A., Esmaelii, H.Z, Rostami, H., Vatandoust, S. and Moradkhani, Z. (2011) Age, reproduction and fecundity of a population of Cobitis sps. (Actinoptergii:Cypriniformes: Cobitidae) from the Babolrud River in the Southern Caspian sea basin. Acta Ichthyologica Et Piscatoria 41 (2): 117-122.

Singh, R. (2004) Some aspects of fish biology and parasitology of Noemacheilus botia (Ham) from Khoh river D. Phil. Thesis. HNB Garhwal University, Srinagar Garhwal.

Uniyal, S.P.(2003). Fish biological Investigations on Tor chilinoides (McClelland). Correlated with its habitat ecology In the Western Nayar. D.Phil. Thesis. HNB Garhwal University, Srinagar Garhwal. 